\title{
The sedimentology of the modern lagoons in the Western Peloponnesus
}

\author{
N. KONTOPOULOS(1) \& D. BOUZOS(1)
}

\begin{abstract}
The Gulfs across of the western Peloponnese are characterized by lagoons. These are located between promontories, in coastal areas where the tidal range is very low. The studied lagoons are very shallow and the sandy mud lithology is the dominant type of the lagoonal bottom sediments. The main hydraulic mechanism for the distribution of the bottom sediments is the winnowing effect by wind action. Further, the studied sediments are characterized as very poorly to extremely poorly sorted and, therefore, the lagoonal environment is one of a very low energy. In this environment the velocity of the depositional agent either fluctuates wide or presents greater consistency. In the bottom sediments, the carbonate and organic material are mostly clastic with an average value of about $35 \%$ and $3 \%$ respectively. The presence of an abundant clay fraction in the lagoonal sediments allows the precipitation of organic carbon. The latter should be always evaluated when solution to environmental problems is required.
\end{abstract}

Keywords: Greece, sediments, lagoons, Western Peloponnesus.

\section{INTRODUCTION}

The west coast of the Peloponnese is characterized by: a. a micro-tidal range. b. a long nearly linear shoreline. c. a low relief. $d$. the mouth of three permanent-Pineos, Alfios, Nedaand some intermittent streams and e. a number of bays and promontories (Gulf: Kyllinios, CheIonitis, Kyparissiakos, Navarino and Headlands: Pappas, Kounoupeli, Kyllini, Tripiti, Katakolo, Methoni).These features are responsible for the presence of a series of lagoons in the western Peloponnese coast, which are: a. the lagoon Pappas $b$. the lagoon Kalogrias $c$. the lagoon Kotychi. d. the lagoon Mouria (drained). e. the lagoon Agoulinitsa (drained). g. the lagoon Kaiafas. h. the lagoon Gialova. These lagoons are very important ecosystems but have lately suffered many environmental problems.

The purpose of this study is to understand the spatial pattern of sediment accumulation, which is an important factor for the restoration of the lagoon ecosystems.

\section{METHODS}

Systematic sample collection was made from the bottom of the lagoon with the use of a Van Veen sampler in a number of sites. A GPS receiver and grid coordinates were used to record and relocate the sampling sites. The sampling depth was measured with tape measure. Mechanical analysis of the sediments was carried out by dry and wet sieving. The various graphic measures were calculated with the use of the formulae of Folk and Ward (1957). Textural terminology is based on Folk (1974). The calcium carbonate and organic carbon was calculated with the Barnavas (1979) and Claudette et al. (1974) methods respectively.

\section{RESULTS}

\section{A. Gialova Lagoon} 1a).

i. Geomorphic and geological setting (Fig.

The Gialova lagoon is located in the southwestern end of Peloponnesus and particularly on the northern coast of Navarino bay. Before 1950 the mouth of the Xerolagados River was found in the middle of the northern lagoon margin. The river poured fine sediment (sand, silt, clay) into lagoon. The source area of these sediments was the Plio-Pleistocene and Pleistocene deposits of the mountainous course of the Xerolagados River and the Holocene sediments of

${ }^{1}$ University of Patras Department of Geology 

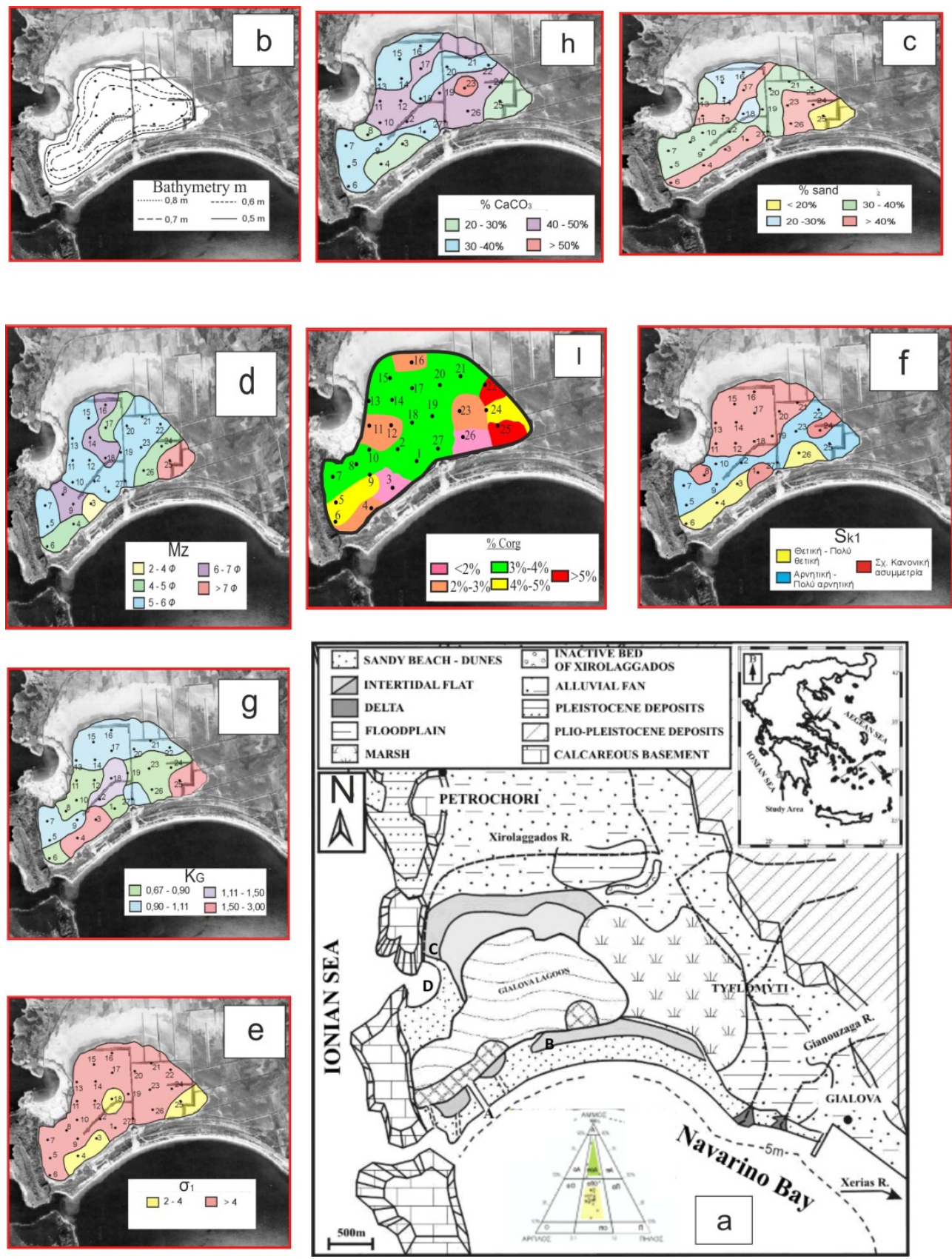

Figure 1. a. Geological map of the area around the Gialova lagoon and the lithological type distribution in the lagoon with the diagram of Folk (1974). b. Bathymetric map with the location of surface sediment samples. c. Distribution of percentage of sand. $d$. Distribution of graphic mean size $\left(\mathrm{M}_{\mathrm{z}}\right)$. e. Distribution of inclusive graphic standard deviation $\left(\sigma_{i}\right)$. f. Distribu- tion of inclusive graphic skewness $\left(\mathrm{Sk}_{\mathrm{i}}\right)$. g. Distribution of graphic kurtosis $\left(\mathrm{K}_{\mathrm{G}}\right)$. h. Distribution of percentage of CaCO3. i. Distribution of percentage of organic carbon $\left(\mathrm{C}_{\mathrm{org}}\right)$. 
the lowland area of the river. The Tiflomity springs occurred in the eastern lagoon margin and which poured fresh water into the lagoon and the marshes of Gianouzagas River. During the 50s the Xerolagados River diversion to the Voidokilia bay and the flow of the Tiflomity spring waters through an artificial canal in the Navarino bay redu-ced the lagoon area from $7.5 \mathrm{~km}^{2}$ to just $2.5 \mathrm{~km}^{2}$. In the middle $80 \mathrm{~s}$ an artificial stable inlet was made on the barrier island which restricts the lagoon from Navarino bay, in the frames of pisciculture installations. However, in the next few years the opening of the inlet and the deficiency of freshwater from the Xirolagados River and Tiflomity springs led to increased salinity and the production of inhospitable conditions in the wetlands of the Gialova lagoon.

\section{ii. Bathymetry (Fig. 1b).}

The Gialova lagoon is very shallow with a maximum depth of $0.80 \mathrm{~m}$ and an average depth of $0.66 \mathrm{~m}$. The greatest depths occur in the central parts of the lagoon. Moreover, at the north lagoon margin the decrease of depth becomes relatively gradual while the depth decreases more abruptly behind the barrier island.

\section{iii. Sedimentology}

a. Lithological types (Fig.1a, 1c).

The majority of the samples belong to the sandy mud class while a few samples to the muddy sand class. The quantitative and spatial distributions of the sand fraction show that behind the barrier island this exceed $40 \%$. Also, there is a narrow zone that has the same high quantities of sand and which begins from the old mouth of the Xerolagados River and ends in the central part of the west lagoon margin.

b. Median ( $\mathrm{Md}$ )(Table 1)

The $M_{d}$ varies between $2.2 \varphi$ and $7.4 \varphi$ and an average $M_{d}$ value of $5.55 \varphi$.

c. Mean size ( $\mathrm{Mz}$ ) (Fig.1d) (Table 1)

The $\mathrm{M}_{\mathrm{z}}$ varies considerably and does not related to $\sigma_{i}$ and $S k_{i}\left(R^{2}=0.08, R^{2}=0.19\right)$. The more fine clastic sediments occur at the south end of the eastern lagoon margin where $\mathrm{M}_{\mathrm{z}}$ is $>7 \varphi$. On the contrary, the more coarse clastic sediments occur near the artificial inlet behind the barrier island. Also, grain size zones are alternated in the northern and the eastern margin of the lagoon where the Mz values belong to the very coarse silt, the medium silt and the fine silt.

Table1. Bathymetric data, particle size analysis results, carbonate and organic carbon content of the Gialova lagoon bottom sediments.

\begin{tabular}{|c|c|c|c|c|c|c|c|c|c|c|c|c|}
\hline SAMPLE & $\begin{array}{l}\text { DEPTH } \\
(\mathrm{m})\end{array}$ & $\begin{array}{c}\text { SAND } \\
\%\end{array}$ & $\begin{array}{c}\text { SILT } \\
\%\end{array}$ & $\begin{array}{c}\text { CLAY } \\
\%\end{array}$ & LITHOLOGY & $\begin{array}{c}\mathrm{CaCO}_{3} \\
\%\end{array}$ & $\begin{array}{l}\mathrm{C}_{\text {org }} \\
\%\end{array}$ & $\begin{array}{l}M d \\
(\varphi)\end{array}$ & $\begin{array}{l}\mathrm{Mz} \\
(\varphi)\end{array}$ & $\begin{array}{c}\sigma_{1} \\
(\varphi)\end{array}$ & SK & $K_{G}$ \\
\hline ya1 & 0,70 & 41,88 & 26,73 & 31,38 & sM & 39,98 & 3,00 & 6.45 & 5,58 & 4,61 & 0,04 & 0,81 \\
\hline ya2 & 0,75 & 31,44 & 42,20 & 26,36 & SM & 41,77 & 3,32 & 2,40 & 5,28 & 4,51 & $-0,13$ & 1,11 \\
\hline ya3 & 0,60 & 83,04 & 7,54 & 9,42 & $\mathrm{mS}$ & 26,08 & 1.45 & 7.40 & 2,15 & 3,05 & 0,17 & 2,56 \\
\hline ya4 & 0,65 & 56,21 & 28,08 & 15,71 & $\mathrm{mS}$ & 22,49 & 2,20 & 4,50 & 4,75 & 3,13 & 0,47 & 1,89 \\
\hline ya5 & 0,75 & 37,09 & 35,57 & 27,33 & sM & 37,97 & 4,45 & 5,75 & 5,30 & 4,83 & $-0,11$ & 0,98 \\
\hline ya6 & 0,45 & 51,13 & 20,06 & 28,81 & $\mathrm{mS}$ & 34,99 & 2,49 & 6,50 & 4,83 & 4,88 & 0,22 & 0,89 \\
\hline ya7 & 0,65 & 31,05 & 35,13 & 33,83 & sM & 38,55 & 3,65 & 5,70 & 5,87 & 5,11 & $-0,16$ & 0,98 \\
\hline ya8 & 0,60 & 35,98 & 28,42 & 35,60 & SM & 28,10 & 3,85 & 5,80 & 6,27 & 4,63 & $-0,08$ & 0,83 \\
\hline ya9 & 0,80 & 31,61 & 30,74 & 37,65 & SM & 38,15 & 4,16 & 6,20 & 6,23 & 4,87 & $-0,13$ & 0,90 \\
\hline ya10 & 0,75 & 35,82 & 34,31 & 29,87 & sM & 44,50 & 3,55 & 6,20 & 5,57 & 4,88 & $-0,13$ & 0,87 \\
\hline ya11 & 0,75 & 41,57 & 31,13 & 27,30 & sM & 45,91 & 2,90 & 5,00 & 5,23 & 4,74 & $-0,04$ & 0,87 \\
\hline ya12 & 0.55 & 40,26 & 27.14 & 32,60 & SM & 40,41 & 2.70 & 6.20 & 5,55 & 5.02 & -0.08 & 0.82 \\
\hline ya13 & 0,60 & 35,32 & 36,85 & 27,83 & sM & 38,16 & 3,60 & 6,30 & 5,32 & 4,73 & $-0,06$ & 1,00 \\
\hline ya14 & 0,70 & 28,92 & 38,40 & 32,68 & SM & 39,03 & 3,42 & 6,20 & 6,63 & 5,16 & 0,01 & 1,01 \\
\hline ya15 & 0,60 & 27,00 & 41,15 & 31,85 & SM & 34,21 & 3,40 & 5,50 & 5,98 & 4,52 & $-0,07$ & 1,05 \\
\hline ya16 & 0,50 & 28,93 & 38,40 & 32,67 & sM & 35,43 & 2,26 & 5,80 & 6,07 & 4,73 & $-0,05$ & 0,94 \\
\hline ya17 & 0,75 & 44,89 & 30,10 & 25,01 & SM & 47,34 & 3,40 & 5,40 & 4,70 & 5,00 & $-0,08$ & 0,96 \\
\hline ya18 & 0,75 & 20,16 & 46,84 & 33,00 & SM & 38,75 & 3,72 & 6,00 & 6,55 & 3,90 & 0,07 & 1,36 \\
\hline ya19 & 0,80 & 36,71 & 31,15 & 32,15 & sM & 46,71 & 3,10 & 6,70 & 5,90 & 4,78 & $-0,09$ & 0,89 \\
\hline ya 20 & 0,60 & 30,11 & 34,50 & 35,38 & SM & 33,02 & 3,88 & 6,50 & 5,77 & 4,98 & $-0,04$ & 0,92 \\
\hline ya21 & 0.50 & 33,70 & 40,81 & 25.49 & SM & 45.31 & 3,60 & 6.35 & 5,57 & 4.82 & $-0,03$ & 0.92 \\
\hline ya22 & 0,40 & 33,11 & 34,99 & 31,90 & sM & 32,04 & 5,90 & 3,90 & 5,27 & 4,61 & $-0,34$ & 0,93 \\
\hline ya23 & 0,75 & 44,05 & 24,92 & 31,03 & SM & 55,96 & 2,65 & 5,70 & 5,25 & 4,83 & $-0,12$ & 0,83 \\
\hline ya24 & 0,80 & 46,66 & 33,11 & 20,23 & $s M$ & 45,51 & 4,15 & 3,80 & 4,10 & 4,89 & $-0,07$ & 0,86 \\
\hline ya 25 & 0,70 & 13,55 & 45,84 & 40,61 & sM & 20,54 & 5,90 & 2,20 & 7,48 & 3,64 & $-0,11$ & 1,95 \\
\hline ya26 & 0,75 & 65,00 & 13,15 & 21,85 & $\mathrm{mS}$ & 47,62 & 1,74 & 5,80 & 4,00 & 4,61 & 0,46 & 0,85 \\
\hline yа27 & 0,70 & 35,70 & 29,91 & 34,39 & sM & 40,46 & 3,30 & 5,50 & 5,88 & 4,55 & $-0,16$ & 1,00 \\
\hline
\end{tabular}


d. Sorting (Fig. 1e) (Table 1)

The majority of the samples are extremely poorly sorted $\left(\sigma_{1}>4 \varphi\right)$. The sediments that occur in the vicinity of the inlet, in the lagoon center and in a small area behind the barrier island are only very poorly sorted $\left(\sigma_{l}=2 \varphi-4 \varphi\right)$.

e. Skewness (Fig.1f) (Table 1)

The skewness values of the lagoon bottom sediments vary considerably. $50 \%$ of the samples have near-symmetrical nature, 30\% are fine-skewed, $4 \%$ are strongly fine-skewed and $8 \%$ are strongly coarse-skewed. The spatial distribution of skewness values exhibits three zones.

The first zone is a narrow strip along the barrier island corresponding to fine-skewed and strongly fine-skewed values. The second is a narrow strip also, parallel to the previous zone, showing coarse-skewed and strongly coarseskewed values. The third zone occupies the rest portion of the lagoon bottom showing nearsymmetrical values (central and northern part of the lagoon).

f. Kurtosis (Fig. 1g) (Table 1)

The kurtosis values show a wide fluctuation and vary from platykurtic to very leptokurtic. $37 \%$ of the samples show platykurtic values, $45 \%$ mesokurtic values, $8 \%$ leptokurtic values and $11 \%$ very leptokurtic values. Most of the samples (82\%) exhibit platykurtic and meso-kurtic curves. The lagoon bottom sediments consist of only mesokurtic curves in the northern part, while there is a variety of kurtosis on the basis of its spatial distribution in the rest of the lagoon.

g. Calcium carbonate (Fig.1h) (Table 1)

The content of $\mathrm{CaCO}_{3}$ in the sediments varies between $20.54 \%$ and $55.96 \%$, while the avera-ge value is $38.48 \%$. This content shows strong fluctuations in the east part of the lagoon while over the wider area of the lagoon the calcium carbonate content is more than $38 \%$. The smaller values occur near the artificial inlet. The sand fraction between $0.5 \varphi$ and $2 \varphi$ contains calcareous shell fragments up to $90 \%$ while these are absent in sand classes less than $2 \varphi$. Also, skeletal fragments are scarce in the northern and eastern part of the lagoon. The carbonate content is negatively correlated with the clay content and $\mathrm{M}_{\mathrm{z}}$ if samples $\mathrm{Ya3}, \mathrm{Ya} 4, \mathrm{Ya} 23$ are excluded from the plot $\left(R^{2}=0.52, R^{2}=0.41\right)$.

h. Organic carbon (Fig.1i) (Table 1)

The content of organic carbon varies from $1.45 \%$ to $5.9 \%$. The eastern part of the lagoon has an average organic carbon content of $3.8 \%$. This value is clearly increased in relation to the $3.1 \%$ which is the average organic carbon content in the west part of the lagoon. The difference in the organic carbon content between the two parts of the lagoon is statistically significant. Organic content is positively but weakly correlated with both silt and clay contents $\left(R^{2}=0.41\right.$, $\mathrm{R}^{2}=0.31$ ). In contrast, the organic content is weakly but negatively correlated with the carbonate content, if samples Ya3, Ya4 (muddy sand) are excluded from the plot $\left(\mathrm{R}^{2}=0.33\right)$.

\section{Discussion}

The sorting is relatively constant over the much wider range of mean grain size as previously mentioned. This evidence suggests a calm condition of a "quiet water" environment for the lagoon bottom (Buller \& MacManus, 1972). In the northern part of the lagoon the grain size cumulative curves are nearly symmetrical and mesokurtic. These evidence a single-source area for the sediments of this part of the lagoon which is the load of Xerolagados River (Folk, 1974). After the diversion of the river mouth the lagoon has ceased to accept further sediments and the sediments of the northern part can be characterized as "relict", maintaining their grain size distributions. These "relict" sediments are extremely poorly sorted as a result of the flood events of Xerolagados River. The alternating zones of the $\mathrm{Mz}_{\mathrm{z}}$ values in the northern and eastern margin of the lagoon suggest the shifting of the Xerolagados River mouth. The spatial distribution of skewness shows the presence of a zone with coarse-skewed values parallel to the large axis of the lagoon. These values are the result of the winnowing process which causes the removal of the fine grained tail of distribution (Valia and Cameron, 1977; Martins, 2003). The winnowing process is caused by a resuspension, with the help of the wind action in the very shallow Gialova lagoon. The removed finegrained fraction is deposited again in the zone 
behind the barrier island which is characterized by a high portion of sand. So, sediments with fine-skewed values are produ-ced. In this zone the increased sand content comes from the old inlets and to a lesser extent from the artificial inlet because a lock-gate in this inlet prevents the entry of sand. The presence of the coarseskewed zone represents a non-depositional or erosional area while the fine-skewed zone is an area dominated by the deposition of fine sediments. North of the coarse-skewed zone, the bottom sediments indicate near symmetrical curves. This suggests the absence of the continuous action of the winnowing process (Duane, 1964; Valia \& Cameron, 1977). In fact, during the summer a large part of the zone with nearly symmetrical values could be as dry as today or it could be made shallower. So, these conditions prevented the winnowing process and this zone is an area in a state of flux (Martins, 2003). It is obvious that the energy in the Gialova lagoon environment increases gradually from the northern margin to the barrier island. The increased presence of the organic carbon in the eastern part of the lagoon compared to the western part is the result of its adjacency with the marshes of the Gianouzagas River. The organic material is transported and deposited in the eastern part while a fast burial prevents the oxidation. The fast burial is achieved with the flood conditions of the Xerolagados River. The weakly positive relationship between the organic carbon and the silt and clay fractions is explained by the similar settling velocity of the organic and fine-grained mineral particles (Tyson, 1995) and by the fact that organic matter, as well as contaminants, adsorb onto silt/clay particles given their greater surface area (Rullkötter, 1999). The absence or the extremely small number of calcareous shell fragments which have been observed in most parts of the lagoon, indicates both the proximity of this parts with the old mouth of the Xerolagados River and the negative effects of floods in the life of mollusks. At the same time, the calcium carbonate content shows a weakly negative correlation either with the particle size $\left(M_{z}\right)$ and the percentage of clay fraction or with the organic material. This suggests that the carbonate content increases with the coarsening of the sediments and consists mostly of clastic grains. The low presence of calcium carbonate near the active inlet is due to the entry of quartz sand in the past, as well as today, through the inlets and despite the presence of skeletal material in the coarse sand fraction. This quartz composition reflects the composition of the sand of the Xerias river mouth.

\section{B. Kaiafa Lagoon}

2a).

i. Geomorphic and geological setting (Fig.

The Kaiafa lagoon is located on the coast of Kyparissiakos Gulf in western Peloponnese. It has a length of $2 \mathrm{Km}$, a width of $500 \mathrm{~m}$ and is limited from the Ionian Sea by a sandy barrier island which has a width of approximately 400 $\mathrm{m}$. The carbonate content of the barrier sand ranges from $56 \%$ to $78 \%$ (Panagos et al, 1978). On the barrier island a well developed dune system is found which is interrupted in its northern edge by a narrow artificial inlet connecting the lagoon with the open sea.

Moreover two drainage ditches occur in the southern and northern margins of the lagoon. A relatively large marshy area occurs at the eastern part of the inner margin of the lagoon. At the north-end of the margin, landward and in a short distance, a limestone outcrop (Lapi-thos Mountain) appears, where the caves "Anigridon Nymphon" and "Geranio" bearing hot springs are located.

The Kaiafa lagoon in the mid 70's suffered extensive interventions involving the drainage of a small area in the northern part of the lagoon, the dredging of the lagoon bottom by removing approximately $2 \mathrm{~m}$ of mud, the creation of a concrete platform in the southern margin, the rearranging of the landward side of the barrier island and the creation of tourist facilities.

ii. Bathymetry (Fig. 2b).

The Kaiafa lagoon is relatively shallow with a maximum depth of $8.1 \mathrm{~m}$ and an average depth of $3.29 \mathrm{~m}$. The greatest depths are situated in two small holes which can be found in the proximity of the northern margin of the lagoon where the bottom relief is very steep. On the contrary, the relief in the rest part of the bottom is very low 

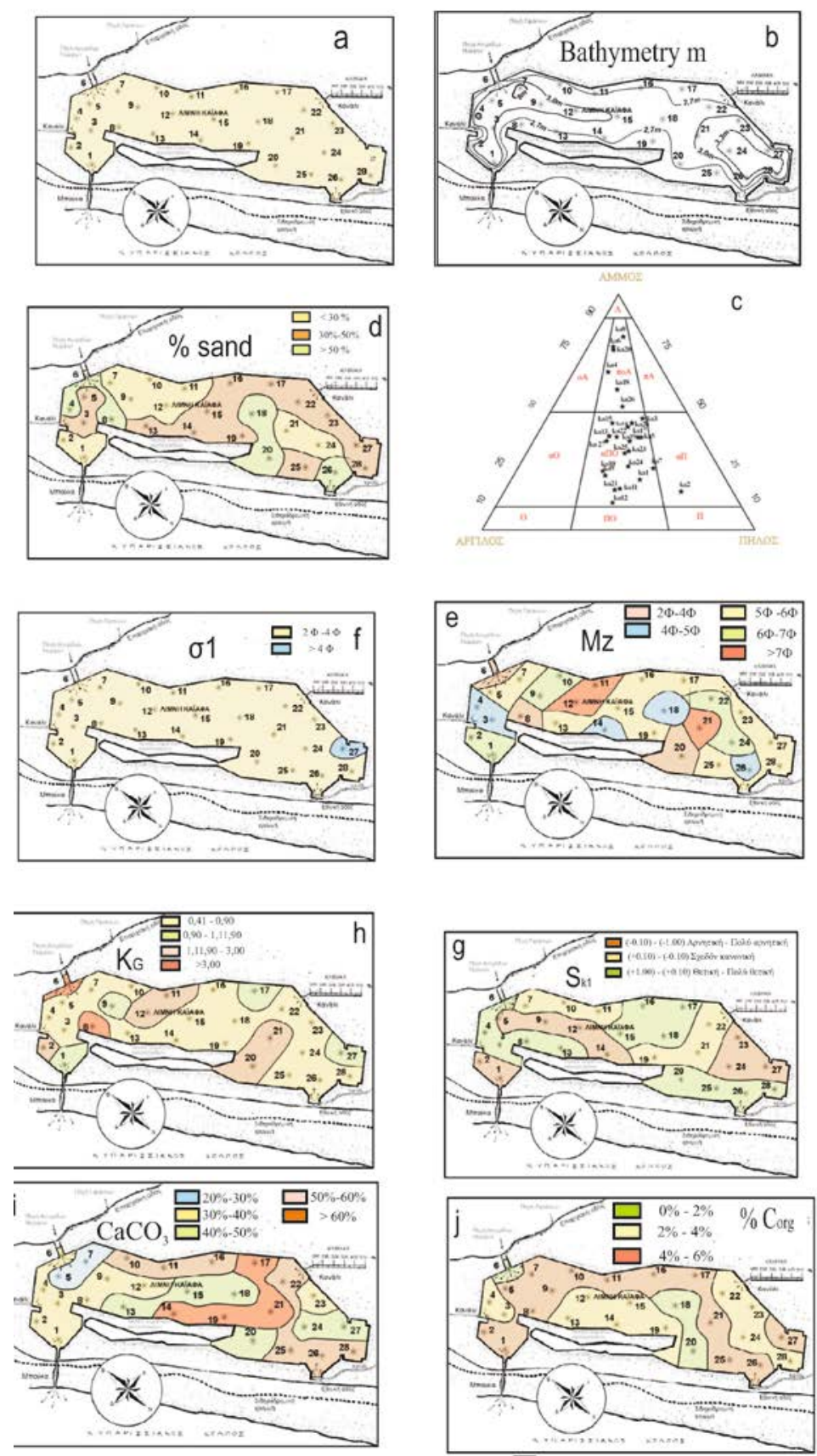

Figure 2. a. A sketch of Kaiafa lagoon and sampling locations. b. Bathymetric map. c. Textural terminology of samples with the diagram of Folk (1974) d. Distribution of percentage of sand. e. Distribution of graphic mean size $\left(M_{z}\right)$. f. Distribution of inclusive graphic standard deviation $\left(\sigma_{i}\right)$. g. Distribution of inclusive graphic skewness $\left(\mathrm{Sk}_{\mathrm{i}}\right)$. h. Distribution of graphic kurtosis $\left(\mathrm{K}_{\mathrm{G}}\right)$. i. Distribution of percentage of $\mathrm{CaCO}_{3}$. j. Distribution of percentage of organic carbon ( $\mathrm{C}_{\mathrm{org}}$ ). 
Table 2. Bathymetric data, particle size analysis results, carbonate and organic carbon content of the Kaiafa lagoon bottom sediments.

\begin{tabular}{|c|c|c|c|c|c|c|c|c|c|c|c|c|}
\hline SAMPLE & $\begin{array}{c}\text { DEPTH } \\
(\mathrm{m})\end{array}$ & $\begin{array}{c}\text { SAND } \\
\%\end{array}$ & $\begin{array}{c}\text { SILT } \\
\%\end{array}$ & $\begin{array}{c}\text { CLAY } \\
\%\end{array}$ & LITHOLOGY & $\begin{array}{c}\mathrm{CaCO}_{3} \\
\% \\
\end{array}$ & $\begin{array}{c}\mathrm{C}_{0 \mathrm{rg}} \\
\%\end{array}$ & $\begin{array}{l}\text { Md } \\
(\varphi)\end{array}$ & $\begin{array}{l}\mathrm{Mz} \\
(\varphi) \\
\end{array}$ & $\begin{array}{c}\sigma_{1} \\
(\varphi)\end{array}$ & $\mathrm{Sk}_{\mathrm{i}}$ & $\mathrm{K}_{\mathrm{G}}$ \\
\hline ka28 & 3,30 & 45,35 & 32,21 & 22,44 & sM & 51,19 & 3,20 & 4,98 & 5,21 & 3,49 & 0,21 & 0,83 \\
\hline ka27 & 3,15 & 37,69 & 26,80 & 29,61 & $s M$ & 43,84 & 6,10 & 6,16 & 5,67 & 4,06 & $-0,15$ & 0,93 \\
\hline ka26 & 3,30 & 52,34 & 25,23 & 22,43 & $\mathrm{~ms}$ & 50,72 & 4,30 & 3,00 & 4,48 & 3,49 & 0.60 & 0,85 \\
\hline ka25 & 2,40 & 32,54 & 36,04 & 28,31 & sM & 58,86 & 4,80 & 5,73 & 5,81 & 3,64 & 0,11 & 0,82 \\
\hline ka24 & 3,50 & 26.98 & 40,07 & 32,95 & $s M$ & 40,90 & 2,18 & 7,40 & 6,07 & 2,98 & $-0,47$ & 0,63 \\
\hline ka23 & 3,15 & 33,44 & 37.06 & 29.50 & sM & 39,90 & 2,90 & 6,60 & 5,85 & 3,04 & $-0,18$ & 0,71 \\
\hline ka22 & 2,85 & 39,47 & 29,60 & 30,93 & sM & 56,36 & 3,16 & 6,00 & 6,02 & 3,63 & 0,10 & 0,76 \\
\hline ka21 & 3,00 & 17.02 & 40.11 & 42.87 & $s M$ & 63,53 & 4,70 & 7,40 & 7,40 & 3,45 & 0,00 & 1.53 \\
\hline ka20 & 2,90 & 76,32 & 9,98 & 13,70 & $\mathrm{~ms}$ & 46,43 & 1,77 & 2,30 & 3,72 & 3,05 & 0,71 & 2,57 \\
\hline ka19 & 2,45 & 37.60 & 35,30 & 27.10 & $s M$ & 64,57 & 3,70 & 5,80 & 5,70 & 3,58 & 0,06 & 0,83 \\
\hline ka18 & 2,80 & 59,58 & 19,72 & 20,70 & $\mathrm{~ms}$ & 44,18 & 1,85 & 2,50 & 4,27 & 3,30 & 0,78 & 0,83 \\
\hline ka17 & 2,60 & 39,26 & 37,55 & 23,18 & $S M$ & 67,21 & 5,50 & 5,10 & 5,80 & 3,74 & 0,27 & 0,97 \\
\hline ka16 & 2,70 & - & - & - & - & - & - & - & - & - & - & - \\
\hline ka15 & 2,95 & 45,34 & 25,09 & 29,57 & $s M$ & 47,75 & 3,34 & 5,00 & 5,77 & 3,79 & 0,33 & 0,75 \\
\hline ka14 & 2,80 & 43,77 & 31,53 & 24,70 & sM & 60,03 & 3,80 & 5,45 & 4,13 & 2,44 & $-0,55$ & 0,81 \\
\hline ka13 & 2,70 & 39,81 & 26,67 & 33,52 & sM & 48,66 & 3,85 & 5,45 & 5,90 & 3,85 & 0,21 & 0,75 \\
\hline ka12 & 3,05 & 11.55 & 42.04 & 46,41 & sM & 36,01 & 3,70 & 7,80 & 7,20 & 2,37 & $-0,35$ & 1,75 \\
\hline ka11 & 2,70 & 17,46 & 41,79 & 40,75 & $s M$ & 56,30 & 4,72 & 7,50 & 7,47 & 3,45 & $-0,01$ & 1,18 \\
\hline ka10 & 2,90 & 25,01 & 31,73 & 43,27 & $s M$ & 55,08 & 4,00 & 7,30 & 7,00 & 3,95 & $-0,04$ & 0,81 \\
\hline ka9 & 3,10 & 23.10 & 33.59 & 43,31 & $s M$ & 38,95 & 5,00 & 7,50 & 6,72 & 3,66 & $-0,17$ & 1,06 \\
\hline ka8 & 2,55 & 81.96 & 10,78 & 7,26 & $\mathrm{~ms}$ & 36,69 & 4,82 & 2,20 & 2,53 & 2,68 & 0,26 & 3,45 \\
\hline ka7 & 8,10 & 26.18 & 49.69 & 24.13 & $\mathrm{sM}$ & 22,18 & 6,10 & 6,50 & 5,95 & 3,24 & $-0,08$ & 0.88 \\
\hline ka6 & 2,85 & 77,78 & 9,15 & 13,07 & $\mathrm{~ms}$ & 30,50 & 1,96 & 2,35 & 3,65 & 2,85 & 0,75 & 3,80 \\
\hline ka5 & 3,35 & 39,26 & 38,66 & 22,08 & $\mathrm{sM}$ & 26,15 & 4,45 & 7,10 & 5,88 & 3,01 & $-0,36$ & 0,72 \\
\hline ka4 & 8,00 & 66,99 & 12,69 & 20,33 & $\mathrm{mS}$ & 32,62 & 2,18 & 2,45 & 4,32 & 3,27 & 0,83 & 0,90 \\
\hline ka3 & 3,00 & 47,30 & 35,20 & 17,50 & sM & 36,07 & 3,25 & 4,35 & 4,97 & 2,49 & 0,32 & 0,58 \\
\hline ka2 & 2,95 & 16,27 & 64,83 & 18,90 & $s z$ & 32,22 & 4,30 & 7,00 & 6,37 & 2,50 & $-0,27$ & 1,81 \\
\hline ka1 & 3,05 & 21,36 & 47,15 & 31,49 & SM & 35,57 & 4,45 & 7,00 & 6,13 & 3,04 & $-0,22$ & 1,01 \\
\hline
\end{tabular}

except from a small part of the southern margin and of the central part behind the barrier island.

\section{iii. Sedimentology}

a. Lithological types (Fig.2c, 2d).

The majority of the samples belong to the sandy mud class, while a small number of samples to the muddy sand class. The quantitative and spatial distribution of the sand fraction is as follows:

1. From the mouth of the inlet to the position of debarkation in the cave "Anigridon Nymphon" the proportion of sand gradually increases from $20 \%$ to $80 \%$.

2. In the northern part of the eastern margin of the lagoon and in a narrow zone in the central part of the south margin sand rates less than $30 \%$ are recorded.
3. In the southern part of the eastern margin of the lagoon and in the central part behind the barrier island the percentage of sand ranges from $30 \%$ to $50 \%$.

4. In the southern part of the western margin of the lagoon there is a zone in which the sand fraction ranges from $30 \%$ to $50 \%$. This zone is alternating with another zone in which the sand fraction is more than $50 \%$.

b. Median (Md) (Table 2)

The Md varies between $2.2 \varphi$ and $7.8 \varphi$ and the average $M_{d}$ is $5.48 \varphi$.

c. Mean size $\left(\mathrm{M}_{\mathrm{z}}\right)$ (Fig.2e) (Table 2)

The $M_{z}$ shows moderate fluctuation. The more coarse-grained sediments $\left(M_{z}<4 \varphi\right)$ have little presence and are restricted to the ends of the arm which is parallel to the barrier island and in the locality of debarkasion in the cave 
"Anigridon Nymphon". Also, the more fine clastic sediments $\left(M_{z}>7 \varphi\right)$ (very fine silt) have very little presence and occur in a very narrow zone in the central part of the lagoon and in a position near the center of its southern part. The statistical parameter $M_{z}$ ranges from $6 \varnothing$ to $7 \varnothing$ (fine silt) in the outlet of the inlet to the side of the lagoon, in the center of its southern part and in a very narrow zone in its northern part. The $\mathrm{M}_{z}$ values between $4 \varnothing$ and $5 \varnothing$ (coarse silt) occur in four localities behind the barrier island and along the largest axis of the lagoon. However, most part of the lagoon is characterized by $\mathrm{M}_{\mathrm{z}}$ values from 5 $\varnothing$ to $6 \varnothing$ (medium silt). In addition there are alternating zones of $\mathrm{M}_{z}$ with different values which gradually are increased from north to south from $3.65 \varnothing$ to $7.47 \varnothing$. These zones occur in the eastern margin of the northern half part of the lagoon.

\section{d. Sorting (Fig. 2f) (Table 2)}

The majority of the samples are very poorly sorted $(\sigma \mid=2 \varphi-4 \varphi)$. The exception is a position atthe southernmost edge of the lagoon where the sediments show extremely poorly sorting $(\sigma$ = 4.06). Moreover the sorting always remains very poor regardless of the $\mathrm{M}_{\mathrm{z}}$ values.

\section{e. Skewness (Fig.2g) (Table 2)}

The asymmetry of the analyzed samples has a large range of values. $22 \%$ of the samples are almost symmetrical, $33 \%$ have coarse or strongly coarse-skewed values and $44 \%$ have fine or strongly fine-skewed values. The spatial distribution of asymmetry indicates that the mentio-ned values of skewness can be alternating in both the northern and the southern part of the lagoon.

f. Kurtosis (Fig. 2h) (Table 2)

The kurtosis values show wide fluctuation and vary from very platykurtic to extremely leptokurtic. $63 \%$ of the samples show values from very platykurtic to platykurtic, $15 \%$ mesokurtic and $22 \%$ from leptokurtic to extremely leptokurtic values. The areal distribution of the kurtosis value shows that there is a greater variety of kurtosis values in the northern part compared to the kurtosis values at the southern part of the lagoon.

g. Calcium carbonate (Fig.2i) (Table 2)

The content of $\mathrm{CaCO}_{3}$ in the sediments varies between $22.67 \%$ and $67.21 \%$, while the ave- rage value is $45.28 \%$. The spatial distribution of calcium carbonate shows that $\mathrm{CaCO}_{3}$ values from $20 \%$ to $40 \%$ occur in the northern part of the lagoon, while the rest part of the lagoon is characterized exclusively by higher values more than $40 \%$.

h. Organic carbon (Fig.2j) (Table 2)

The percentage of organic carbon in the analyzed samples varies from $1.77 \%$ to $6.10 \%$ while the average value is $3.85 \%$. Also, the organic carbon content is positively correlated with the percentile of the silt fraction $\left(R^{2}=0.55\right)$. The spatial distribution of values of $\mathrm{C}_{\text {org }}$ in the bottom of the lagoon indicates very low values in a narrow zone at the southern end of the arm of touristic facilities and in the locality of debarkation in the cave "Anigridon Nymphon". By contrast, higher values (4\%-6\%) have a significant presence throughout of the lagoon, especially in the eastern margins and in the northern and southern part of the lagoon. Intermediate values (2\%-4\%) are mainly confined to the central part of the lagoon behind the barrier island, i.e. in the western margins. Also, these values occur in the southern part of the lagoon and its northern margin.

\section{Discussion}

The Kaiafa lagoon is relatively shallow and its bathymetry depends on the free water level of a cold karst aquifer occurring in the Upper Cretaceous limestones adjacent of the lagoon. The changes in this water level cause changes in the bathymetry of the lagoon (Dimopoulos \& Mountrakis, 1989). Most part of the sediments that cover the seabed of the lagoon is characterized as sandy silt. Where the sand fraction is increased, this is directly related to the transportation by the wind from the adjacent barrier island and from the drainage ditches in the southern and northern margins of the lagoon. Most of the bottom sediments of the lagoon are characterized by a mean size which belongs to the class of medium coarse silt. The sorting of the lagoon sediments is very poor because of the significant absence of wave or current action (low energy environment). Phi skewness varies between coarse-skewed and strongly-fine values. This suggests the presence of winnowing action (erosion process) and the process of 
addition of suspension material (deposition process). The kurtosis values are mostly under 1.00. This suggests that the velocity of the depositional agent fluctuates wide (Greenwood, 1969). The average amount of $\mathrm{CaCO}_{3}$ is $45 \%$. This can be supplied either by eolian action which operates on the barrier island, or by fluvial action deriving from the fine fraction of the sand within the drainage basin of the lagoon, which is covered by limestones and by calcareous deposits of biogenic origin from calcareous lagoon organisms. The surrounding vegetation (marsh) on the eastern lagoonal margin is the source area for the increased organic content in the lagoon bottom sediments. The interpretation of the positive relationship between the organic content and silt fraction has been interpreted previously.

\section{Kotihi Lagoon} $\left.3 A_{a, b}\right)$.

i. Geomorphic and geological setting (Fig.

The Kotihi lagoon is located on the coast of northwestern Peloponnesus, about $40 \mathrm{~km}$ southwest of the city of Patras. The lagoon is approximately orthogonal in shape and is situated on 6.32 ha of flat land at the northeastern tip of the Paleo-Peneus River. Westwards it is separated from the open sea by a low relief barrier island and has limited communica-tion with the open sea, with a stable, short and narrow inlet. Eastwards, the lagoon is limited by a modern alluvial plain made of a number of torrent systems and on the landward lagoonal margins small-scale deltas of these systems have prograded into the lagoon. Intertidal and supratidal mud flats are developed among the deltas, covered with plants, e.g. Salicornia. Northwards, the lagoon is limited by a large marshy area. North of this area a group of well-developed beach ridges parallel to the current shoreline is found. These are undergoing erosion, and migrating sand dunes, have buried some of the beach ridges. South of the lagoon the old Peneus river delta is located.

ii. Bathymetry (Fig. 3b).

Depths in the Kotihi lagoon decrease gradually with distance from the landward site of the barrier island to the inner lagoon margins. Although the maximum depth is $2.5 \mathrm{~m}$ in front of the inlet, the average depth is only $0.5 \mathrm{~m}$. Four artificial, very shallow channel-like features run at right angles to the barrier coast and one almost parallel to this coast.

\section{iii. Sedimentology}

a. Lithological types (Fig. 3Ab, 3c).

The main lithological type of the lagoon sediments is sandy mud, with some exceptions in the eastern edge of the lagoon and some locations around the lagoon where thinner material of silt-clay has been deposited. The sand lithology is almost absent from the lagoon sediments and is restricted only in a narrow zone at the sea side of the inlet. The shell fragment contribution to the lagoonal bottom sediment ranges from $2 \%$ to $10 \%$.

b. Median ( $\mathrm{Md}$ ) (Table 3).

The $M_{d}$ varies between $2.2 \varphi$ and $7.8 \varphi$ and the average $M_{d}$ is $5.48 \varphi$.

c. Mean size (Mz) (Fig.3d) (Table 3).

The distribution of mean size displays three small regions that are covered by finer sediments. These are: i. the area close to the marsh environment. ii. The zone in front of the Gouvos river mouth and iii. The part of the lagoon just behind the north-eastern part of the barrier island. The rest of the lagoon is characterized by coarser materials. The pattern of mean size distribution does not relate with the water depth $\left(\mathrm{R}^{2}=0,0002\right)$.

d. Sorting (Fig.3e) (Table 3).

The sorting fluctuates between $1.82 \varphi$ and $5.30 \varphi$ with an average of $3.57 \varphi$. The sediments are very poorly to extremely poorly sorted.

e. Skewness (Fig.3f) (Table 3).

The skewness varies from -0.64 to 0.17 . The major part of the lagoon is covered with coarse to very coarse skewed sediments. The near symmetrical and fine skewed sediments constitute only $27 \%$ of the lagoon and occur mostly in the first two mentioned small regions. The skewness indicates positive correlation with mean size $\left(R^{2}=0.51\right)$. Particularly, the negative skewness values change to near symmetrical and then to fine skewed values as the mean size decreases in its $\varphi$ values.

f. Kurtosis (Fig.3g) (Table 3)

The kurtosis varies from 0.72 to 3.13 . The major part of the lagoon is covered with meso- 

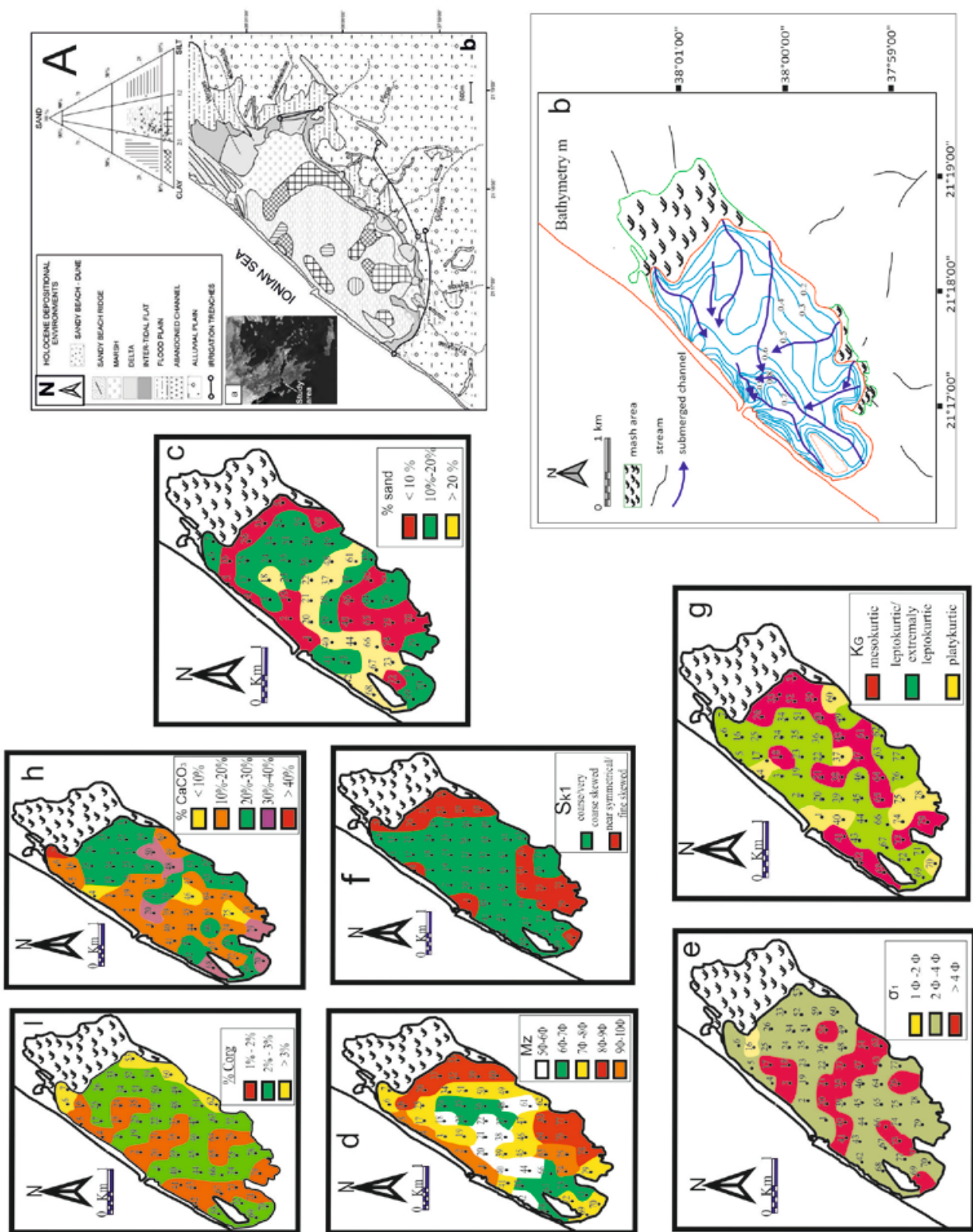

Figure 3. $A_{a}$ The location of the studied lagoon. Ab. Geological map of the area around the Kotihi lagoon, and the distribution of the lithological type in the lagoon. b. Bathymetric map with the location of surface sediment samples. c. Distribution of percentage of sand. d. Distribution of graphic mean size $\left(\mathrm{M}_{\mathrm{z}}\right)$. e. Distribution of inclusive graphic standard deviation $\left(\sigma_{i}\right)$. f. Distribution of inclusive graphic skewness $\left(S k_{i}\right)$. g. Distribution of graphic kurtosis $\left(\mathrm{K}_{\mathrm{G}}\right)$. h. Distribution of percentage of $\mathrm{CaCO}$. i. Distribution of percentage of organic carbon (Corg). 
Table3. Bathymetric data, particle size analysis results, carbonate and organic carbon content of the Kotihi lagoon bottom sediments.

\begin{tabular}{|c|c|c|c|c|c|c|c|c|c|c|c|c|}
\hline SAMPLE & $\begin{array}{l}\text { DEPTH } \\
(\mathrm{m})\end{array}$ & $\begin{array}{c}\text { SAND } \\
\%\end{array}$ & $\begin{array}{c}\text { SILT } \\
\%\end{array}$ & $\begin{array}{c}\text { CLAY } \\
\%\end{array}$ & LITHOLOGY & $\begin{array}{c}\mathrm{CaCO}_{3} \\
\%\end{array}$ & $\begin{array}{l}\mathrm{C}_{\alpha r g} \\
\%\end{array}$ & $\begin{array}{l}\text { Md } \\
(\varphi)\end{array}$ & $\begin{array}{l}M z \\
(\varphi)\end{array}$ & $\begin{array}{c}\sigma_{1} \\
(\varphi)\end{array}$ & Sk & $K_{G}$ \\
\hline ko79 & 0,40 & 13,46 & 46,92 & 39,62 & SM & 38,75 & 1,95 & 6,90 & 7,48 & 3,55 & 0,18 & 0,91 \\
\hline ko78 & 0,35 & 3,40 & 39,89 & 56,71 & $M$ & 11,50 & 2,24 & 8,50 & 8,83 & 2,90 & 0,13 & 0,81 \\
\hline ko77 & 0,30 & 15,10 & 41,65 & 43,25 & SM & 23,59 & 2,13 & 7,40 & 6,98 & 3,37 & $-0,23$ & 1,62 \\
\hline ko76 & 0,35 & 14,14 & 32,54 & 53,32 & SM & 15,72 & 1,58 & 8,30 & 8,25 & 4,18 & $-0,16$ & 1,13 \\
\hline ko75 & 0,25 & 1,77 & 32,30 & 65,93 & $\mathrm{C}$ & 9,22 & 2,64 & 9,40 & 9,33 & 2,87 & $-0,03$ & 0,72 \\
\hline ko74 & 0,45 & 5,46 & 34,65 & 59,89 & $M$ & 14,01 & 2,01 & 9,00 & 9,03 & 3,16 & $-0,03$ & 0,80 \\
\hline ko73 & 0,45 & 23,15 & 28,00 & 48,85 & SM & 28,30 & 1,95 & 7,90 & 6,77 & 5,26 & $-0,30$ & 0,99 \\
\hline ko72 & 0,40 & 7,76 & 33,41 & 58,84 & M & 14,46 & 2,1 & 8,15 & 7,45 & 2,30 & $-0,46$ & 1,70 \\
\hline ko71 & 0,40 & 16.86 & 39,79 & 43,36 & sM & 20,18 & 1.73 & 7,45 & 6,67 & 3,37 & $-0,35$ & 1,57 \\
\hline ko70 & 0,35 & 10,89 & $\begin{array}{l}47,48 \\
\end{array}$ & 41,63 & SM & 31,54 & 2,15 & 7,30 & 7,77 & 3,42 & 0,14 & 0,89 \\
\hline ko69 & 0.35 & 16.06 & 35,53 & 48,40 & sM & 20.78 & 2,43 & 7,85 & 7,75 & 4,40 & $-0,15$ & 1,12 \\
\hline ko68 & 0,40 & 25,91 & 30,81 & 43,28 & SM & 34,15 & 2,22 & 7,30 & 6,07 & 3,40 & $-0,43$ & 1,03 \\
\hline ko67 & 0,55 & 22,92 & 34,86 & 42,22 & SM & 16.05 & 1,80 & 7,40 & 6,20 & 3,72 & $-0,39$ & 1,30 \\
\hline ko66 & 0,50 & 24,96 & 35,77 & 39,27 & sM & 28,44 & 2,10 & 7,00 & 6,13 & 5,30 & $-0,23$ & 1,12 \\
\hline ko65 & 0,45 & 7,40 & 30,00 & 62,60 & C & 15,12 & 1,95 & 8,80 & 9,02 & 3,27 & $-0,04$ & 1,01 \\
\hline ko64 & 0,45 & 11,31 & 35,87 & 52,81 & sM & 18,88 & 1,80 & 8,20 & 8,45 & 3,67 & $-0,03$ & 0,95 \\
\hline ko63 & 0,30 & 3,92 & 36,84 & 59,24 & $M$ & 20,07 & 2,97 & 8,20 & 8,20 & 2,45 & 0,05 & 1,52 \\
\hline ko62 & 0,20 & 18,49 & 35,20 & 46,31 & SM & 21,88 & 3,75 & 7,70 & 7,27 & 4,25 & $-0,22$ & 1,47 \\
\hline ko61 & 0,35 & 30,71 & 33,91 & 35,38 & SM & 25,54 & 2,58 & 6,50 & 5,90 & 5,20 & $-0,18$ & 0,95 \\
\hline ko60 & 0,25 & 4,24 & 38,32 & 57,44 & $M$ & 14,68 & 3,15 & 8,50 & 8,83 & 2,94 & 0,12 & 0,84 \\
\hline ko59 & 0,40 & 10,01 & 36,95 & 53,04 & SM & 22,38 & 2,61 & 8,30 & 8,47 & 3,76 & $-0,08$ & 1,10 \\
\hline ko53 & 0,30 & 7.22 & 49,39 & 43.39 & $M$ & 29.12 & 3.03 & 7,60 & 8,10 & 3,03 & 0,17 & 1,05 \\
\hline ko52 & 0,35 & 14,20 & 33,94 & 51,86 & SM & 20,09 & 2,25 & 8,20 & 8,23 & 3,91 & $-0,11$ & 1,07 \\
\hline ko51 & 0,45 & 11,63 & 34,18 & 54,19 & sM & - & 2,51 & 8,10 & 7,33 & 2,67 & $-0,43$ & 1,70 \\
\hline ko50 & 0,45 & 19,24 & 32,98 & 47,77 & sM & 32,02 & 2,46 & 7,80 & 7,53 & 4,31 & $-0,14$ & 1,04 \\
\hline ko49 & 0,40 & 10,45 & 35,91 & 53,64 & SM & 17,07 & 2,60 & 8,10 & 7,38 & 2,37 & $-0,47$ & 1,54 \\
\hline ko48 & 0,50 & 26,79 & 42,69 & 30,52 & SM & 31,12 & 2,06 & 7,10 & 5,37 & 3,88 & $-0,56$ & 0,98 \\
\hline ko47 & 0,40 & 19,84 & 31,22 & 48,94 & sM & 19,58 & 2,26 & 8,00 & 7,27 & 4,67 & $-0,24$ & 1,07 \\
\hline ko46 & 0,50 & 5,96 & 36,63 & 57,41 & $M$ & 6,46 & 2,15 & 8,15 & 7,55 & 2,20 & $-0,34$ & 1,59 \\
\hline ko45 & 0,50 & 9,93 & 39,18 & 50,90 & $M$ & 14,64 & 2,29 & 8,10 & 7,28 & 2,64 & $-0,57$ & 1,77 \\
\hline ko44 & 0,65 & 21,77 & 54,84 & 23,39 & $s z$ & 18,77 & 2,11 & 7,10 & 5,33 & 3,87 & $-0,60$ & 1,58 \\
\hline ko43 & 0,65 & 19,35 & 35,97 & 44,69 & SM & 20,36 & 1,79 & 7,80 & 6,43 & 3,05 & $-0,64$ & 1,29 \\
\hline ko42 & 0,50 & 25,30 & 44,59 & 30,11 & SM & 29,42 & 1,69 & 7,20 & 5,97 & 3,01 & $-0,58$ & 0,91 \\
\hline ko41 & 0,65 & 16,52 & 32,80 & 50,69 & SM & 18.39 & 1,60 & 8,00 & 7,88 & 4,33 & $-0,16$ & 1,08 \\
\hline ko40 & 0,65 & 32,25 & 25,51 & 42,24 & SM & - & 2,10 & 7,30 & 5,52 & 4,29 & $-0,49$ & 0,82 \\
\hline ko39 & 0,70 & 14,26 & 32,71 & 53,04 & $s M$ & 17.79 & 2,52 & 8,10 & 7,08 & 2,89 & $-0,53$ & 1,82 \\
\hline ko38 & 0,55 & - & - & - & - & - & - & - & - & - & - & - \\
\hline ko37 & 0.50 & 25,19 & 30,11 & 44,70 & SM & 23.58 & 1,85 & 7,40 & 6,53 & 5,13 & $-0,23$ & 0,87 \\
\hline ko36 & 0,45 & 17,21 & 37,49 & 45,30 & SM & 21,68 & 2,16 & 7,60 & 6,63 & 3,60 & $-0,39$ & 1,74 \\
\hline ko35 & 0.50 & 15.41 & 34,65 & 49,94 & SM & 20,21 & 1,98 & 8,00 & 6,93 & 3,12 & $-0,54$ & 1,68 \\
\hline ko34 & 0,50 & 13,87 & 37,32 & 48,81 & SM & 20,20 & 2,32 & 7,90 & 7,73 & 3,87 & $-0,19$ & 1,54 \\
\hline ko33 & 0,30 & 6,83 & 42,13 & 51,05 & $M$ & 29,40 & 2,90 & 8,00 & 8,40 & 3,16 & 0,11 & 0,91 \\
\hline ko26 & 0,25 & 6,27 & 31,96 & 61,77 & $M$ & 22,56 & 2,30 & 8,80 & 8,97 & 3,15 & $-0,01$ & 0,96 \\
\hline ko25 & 0,50 & 14,85 & 35,53 & 49,63 & sM & 21,66 & 2,26 & 8,00 & 7,02 & 3,39 & $-0,55$ & 2,08 \\
\hline ko24 & 0,50 & 17,73 & 34,88 & 47,39 & SM & 22,84 & 1,88 & 7,70 & 6,80 & 3,00 & $-0,35$ & 1,42 \\
\hline ko23 & 0.45 & 18,84 & 35,17 & 45,99 & SM & 18.54 & 2,65 & 7,70 & 6,17 & 3,95 & $-0,56$ & 1,93 \\
\hline ko22 & 0,50 & 25,07 & 35,06 & 39,86 & SM & 19,04 & 2,45 & 7,30 & 5,42 & 3,81 & $-0,73$ & 1,14 \\
\hline ko21 & 0,60 & 36,38 & 20,92 & 42,70 & $\mathrm{SC}$ & 28.58 & 1,92 & 7,00 & 5,27 & 4,70 & $-0,49$ & 1,06 \\
\hline ko20 & 0,65 & 25,78 & 39,66 & 34,56 & SM & 31,00 & 1,70 & 7,10 & 5,35 & 4,67 & $-0,53$ & 1,44 \\
\hline ko19 & 0,55 & 9,04 & 37,07 & 53,89 & $M$ & 15,76 & 2,06 & 8,20 & 7,90 & 3,08 & $-0,19$ & 1,68 \\
\hline ko18 & 0,55 & 30,75 & 24,95 & 44,31 & SM & 25,57 & 1,95 & 7,40 & 5,15 & 4,99 & $-0,54$ & 0,94 \\
\hline ko17 & 0.55 & 20,09 & 27,70 & 52.20 & SM & 22.46 & 2.10 & 8,10 & 7,27 & 4,63 & $-0,33$ & 1,53 \\
\hline ko16 & 0,40 & 6,07 & 23,38 & 70,55 & C & 15,89 & 1,56 & 8,40 & 7,93 & 1,82 & $-0,50$ & 3,13 \\
\hline ko7 & 0,30 & 18,21 & 47,36 & 34,43 & SM & 41,88 & 3,21 & 6,80 & 6,98 & 3,80 & 0,01 & 1,39 \\
\hline k06 & 0,30 & 10,48 & 41,89 & 47,63 & SM & 17,44 & 3,06 & 7,85 & 7,28 & 2,41 & $-0,28$ & 1,44 \\
\hline k05 & 0.25 & 5,86 & 21,95 & 72,19 & $C$ & 11.66 & 1,35 & 9,90 & 9,83 & 3,07 & $-0,18$ & 1,17 \\
\hline ko4 & 0,75 & 1,80 & 23,70 & 74,50 & $\mathrm{C}$ & 6,42 & 1,54 & 10,00 & 9,90 & 2,67 & $-0,09$ & 0,82 \\
\hline$k 03$ & 0.55 & 16.65 & 32.98 & 50,37 & SM & 17.82 & 2,00 & 8,00 & 7,83 & 4,41 & $-0,17$ & 1,15 \\
\hline k02 & 0,60 & 7,17 & 23,18 & 69,65 & $\mathrm{C}$ & 12,17 & 1,46 & 9,60 & 9,65 & 3,30 & $-0,16$ & 1,12 \\
\hline ko1 & 2,15 & 2,76 & 33,58 & 63,66 & $M$ & 18,10 & 2,00 & 8,80 & 9,10 & 2,81 & 0,11 & 0,84 \\
\hline
\end{tabular}

kurtic up to very leptokurtic sediments. The platykurtic sediments constitute only $15 \%$ of the lagoon.

g. Calcium carbonate (Fig.3h) (Table 3)
The content of $\mathrm{CaCO}_{3}$ in the sediments varies between $6,42 \%$ and $41,88 \%$, while the average value is $21,13 \%$. The spatial distribution of calcium carbonate shows that the $\mathrm{CaCO} 3$ values from $10 \%$ to $30 \%$ occur in most part of the 
lagoon, while the rest of the lagoon is characterized either from values less than $10 \%$ or from values higher than $30 \%$. The carbonate content indicates negative correlation with clay fraction $\left(R^{2}=0.47\right)$ and weakly positive correlation with the sand fraction $\left(R^{2}=0.31\right)$.

h. Organic carbon (Fig.3i) (Table 3)

The percentage of organic carbon in the analyzed samples varies from $1.46 \%$ to $3.75 \%$, while the average value is $2.20 \%$. The spatial distribution of $\mathrm{C}_{\text {org }}$ values in the bottom of the lagoon indicates low values from $1 \%$ to $2 \%$ in narrow zones which have parallel orientation to the small axis of the lagoon area. However, most part of the lagoon indicates intermediate values from $2 \%$ to $3 \%$, while high values more than $3 \%$ occur in the half part of the landward lagoon margin. There is no correlation between the organic carbon content and the clay and silt fractions $\left(R^{2}=0.02, R^{2}=0.15\right)$.

Discussion

The Kotihi lagoon is very shallow. This can be explained since many streams are poured in the lagoon. Most of the sediments entering the lagoon are from the streams and consist mainly of silt-clay and high organic content. The absence of the fluvial sand is owed by: a. the finegrained material of the source area, $b$. the $a b$ sence of the relief in the drainage basin and $c$. the trapping of the coarse-grained fraction from the irrigation system which is around the landward margin of the lagoon. The sandy mud is the dominant lithology that spreads evenly over the bottom of the lagoon. The finer lithologies occur in front of the stream mouths, in the area nearby the marsh and just behind of the northeastern part of the barrier island as previously mentioned. The first two places of finer sediments may be interpreted as the result of flocculation of clay due to the mixing of stream water with saline lagoonal seawater. However, the third place is the result of the resuspension process, where a finer tail of clay can be added. The very poorly to extremely poorly sorted sediments suggest a low energy environment where the deposition is free from effects of wave and current action. So, the presence mostly of the coarse-skewed deposits shows the dominance of the resuspension process which is a type of erosion. The positive correlation of the mean size against the skewness shows that the resuspension process is dominant. This causes changes in the relative proportion between the lithology of sand, silt and clay. The few platycurtic curves indicate that the velocity fluctuations within the lagoon are capable of carrying particles within the middle of the size distribution (between 25 and 75 percentile) for longer than normal. This perhaps indicates a constancy of energy, with higher values of kurtosis indicating a greater consistency (Greenwood, 1969). The carbonate content shows negative correlation with clay fraction and weakly positive with sand fraction as previously mentioned. This suggests that the carbonate content increases with the coarsening of the sediments and consists mostly of clastic grains. The lack of correlation between organic content and the clay/silt fraction may suggest that the organic material has only a terrigenous character.

\section{Pappas Lagoon} 4a).

i. Geomorphic and geological setting (Fig.

The Pappas lagoon is located at the northwestern end of Peloponnese. It occupies an area of approximately $6.2 \mathrm{~km}^{2}$ and its form resembles with a rectangle which has a length of $5 \mathrm{Km}$ and a width of $1.7 \mathrm{Km}$. The size and the shape of the lagoon are determined by three limestone bodies. These bodies are the borders of the lagoon to the west, south-east and north, while in the space among the limestone hills low sandy barrier islands have developed that confine the northwestern part of the lagoon from the Ionian Sea and the eastern part from the Gulf of Patras. Finally, the lagoon has as southern limit, the alluvial plain of the intermittent stream system that drains the drainage basin of the lagoon. The communication of the lagoon with the open sea becomes from its northern and eastern margins with three inlets which interrupt the sandy barriers. The width of the northwestern sandy barrier reaches the $600 \mathrm{~m}$ with in general low relief, while the width of the eastern sandy barrier 

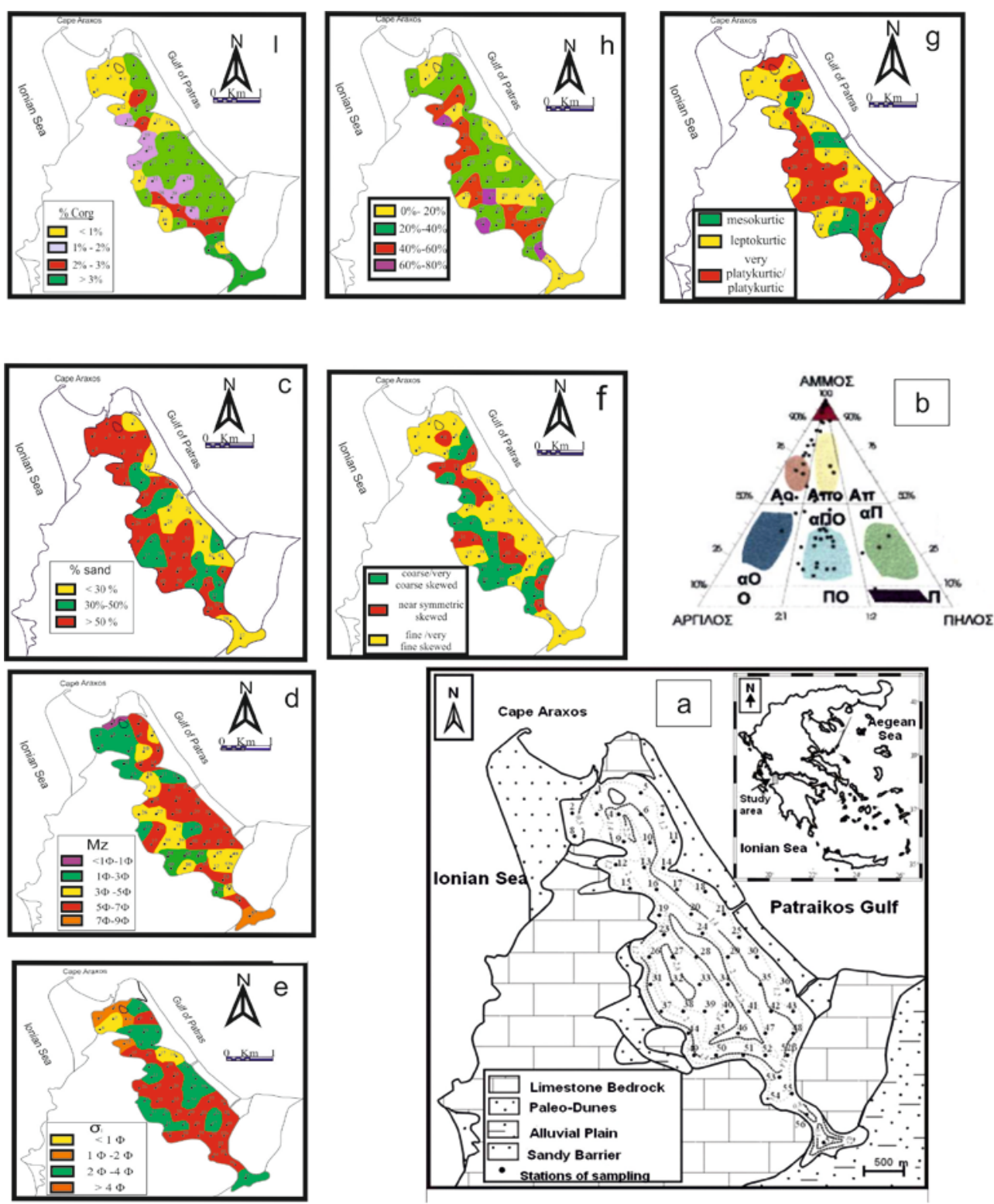

Figure 4. a. The location of the Pappas lagoon, the geological map of the area around the lagoon and bathymetric map with the location of surface sediment samples. b. Textural terminology of samples with the diagram of Folk (1974) c. Distribution of percentage of sand. d. Distribution of graphic mean size $\left(\mathrm{M}_{\mathrm{z}}\right)$. e. Distribution of inclusive graphic standard deviation $\left(\sigma_{i}\right)$. f. Distribution of inclusive graphic skewness $\left(S_{\mathrm{i}}\right)$. g. Distribution of graphic kurtosis $\left(\mathrm{K}_{\mathrm{G}}\right)$. h. Distribution of percentage of $\mathrm{CaCO}$. i. Distribution of percentage of organic carbon (Corg). 
Table 4. Bathymetric data, particle size analysis results, carbonate and organic carbon content of the Pappas lagoon bottom sediments.

\begin{tabular}{|c|c|c|c|c|c|c|c|c|c|c|c|c|}
\hline SAMPLE & $\begin{array}{c}\text { DEPTH } \\
(\mathrm{m})\end{array}$ & $\begin{array}{c}\text { SAND } \\
\%\end{array}$ & $\begin{array}{c}\text { SILT } \\
\%\end{array}$ & $\begin{array}{c}\text { CLAY } \\
\%\end{array}$ & LITHOLOGY & $\begin{array}{c}\mathrm{CaCO}_{3} \\
\%\end{array}$ & $\begin{array}{c}\mathrm{C}_{o r g} \\
\%\end{array}$ & $\begin{array}{l}\mathrm{M}_{\mathrm{d}} \\
(\varphi)\end{array}$ & $\begin{array}{c}\mathrm{Mz} \\
(\varphi)\end{array}$ & $\begin{array}{r}\sigma_{1} \\
(\varphi)\end{array}$ & $\mathrm{Sk}_{1}$ & $K_{G}$ \\
\hline p57 & 0,3 & 14,29 & 38,2 & 47,51 & $\mathrm{sM}$ & 16,50 & 3,18 & 7,80 & 7,92 & 3,34 & $-0,11$ & 0,77 \\
\hline p56 & 0,85 & 28,31 & 26,50 & 45,19 & sM & 16,16 & 3.06 & 7.50 & 6.88 & 4.60 & $-0,15$ & 0.74 \\
\hline p55 & 1,3 & 51,51 & 10,94 & 37,55 & CS & 65,16 & 0,99 & 3,95 & 3,98 & 4,63 & 0,02 & 0,76 \\
\hline p54 & 1,45 & 52,47 & 12,36 & 35,17 & cS & 25,34 & 3.45 & 3.50 & 4.97 & 4.96 & 0,37 & 0.66 \\
\hline $\mathrm{p} 53$ & 2 & 44,83 & 15,97 & 39,20 & $\mathrm{sC}$ & 27,45 & 3,42 & 5,70 & 6,00 & 4,66 & 0,12 & 0,60 \\
\hline p52b & 1,8 & 36,22 & 14,72 & 49,06 & $\mathrm{sC}$ & 54,76 & 2,37 & 3,90 & 4,40 & 4,20 & 0,09 & 0,94 \\
\hline p52 & 2 & 50,95 & 20,30 & 28,75 & $\mathrm{mS}$ & 45,03 & 2,70 & 3,85 & 4,57 & 4,90 & 0,20 & 0,77 \\
\hline p51 & 2,2 & 32,69 & 29,87 & 37,44 & SM & 42,32 & 2,85 & 6,50 & 5,20 & 4,24 & $-0,41$ & 0,95 \\
\hline p50 & 2,25 & 72,85 & 5.08 & 22,07 & $\mathrm{~ms}$ & 27,92 & 3,38 & 0,95 & 3,55 & 4,44 & 0,79 & 1,06 \\
\hline $\mathrm{p} 49$ & 2,3 & 78,26 & 6,25 & 15,49 & $\mathrm{~ms}$ & 64,30 & 0.53 & 2.00 & 2.72 & 4,14 & 0,30 & 1,55 \\
\hline $\mathrm{p} 48$ & 1,75 & 65,71 & 5,53 & 28,75 & $c S$ & 33,39 & 3,38 & 1,50 & 4,10 & 4,76 & 0,70 & 0,68 \\
\hline $\mathrm{p} 47$ & 2 & 36,23 & 32,31 & 31,46 & SM & 35,80 & 3,11 & 6.00 & 4.87 & 3.74 & $-0,37$ & 0,70 \\
\hline $\mathrm{p} 46$ & 2,3 & 74,28 & 5,10 & 20,61 & $c S$ & 68,97 & 1,05 & 0,00 & 2,43 & 5,14 & 0,63 & 1,11 \\
\hline $\mathrm{p} 45$ & 2,45 & 80,61 & 4,32 & 15,07 & $\mathrm{CS}$ & 23,12 & 2.13 & 1.30 & 2.97 & 3.86 & 0,75 & 2.72 \\
\hline $\mathrm{p} 44$ & 2,3 & 89.05 & 4.49 & 6,45 & $\mathrm{~ms}$ & 29,21 & 0,93 & 1,50 & 1,70 & 2,58 & 0,33 & 1,44 \\
\hline p43 & 0,8 & 28,97 & 31,28 & 39,75 & SM & 20,49 & 3,45 & 7.20 & 6.68 & 4.39 & $-0,11$ & 0.71 \\
\hline $\mathrm{p} 42$ & 1,75 & 8,83 & 64,99 & 26,18 & $z$ & 7,19 & 4,50 & 7,25 & 6,97 & 2,43 & $-0,22$ & 2,15 \\
\hline$p 41$ & 2,1 & 33,14 & 34,28 & 32,57 & sM & 18,46 & 4,70 & 6,20 & 6,07 & 4,16 & 0,01 & 0,81 \\
\hline$p 40$ & 2,25 & 28,63 & 38,77 & 32,60 & sM & 17,70 & 3,93 & 6,40 & 6,03 & 4,25 & $-0,05$ & 0,88 \\
\hline p39 & 2,5 & 68,77 & 7,09 & 24,13 & $c S$ & 63,84 & 1,56 & 2,00 & 3,60 & 5,27 & 0,39 & 0,77 \\
\hline p38 & 2,7 & 46,71 & 28,35 & 24,94 & SM & 45,66 & 2,01 & 5,00 & 4.43 & 3,88 & $-0,27$ & 0,74 \\
\hline p37 & 2,6 & 39,73 & 30,43 & 29,84 & SM & 16,52 & 4,31 & 6.10 & 5.50 & 3,38 & $-0,17$ & 0,81 \\
\hline p36 & 1,1 & 32,31 & 32,10 & 35,59 & $\mathrm{sM}$ & 18,00 & 4.03 & 6.80 & 6.33 & 4.45 & $-0,11$ & 0,82 \\
\hline p35 & 1,75 & 20,25 & 29,21 & 50,54 & $\mathrm{sM}$ & 24,31 & 4.35 & 8.00 & 6.33 & 4,21 & $-0,50$ & 1,87 \\
\hline p34 & 2,3 & 84,96 & 5,57 & 9,48 & CS & 29,23 & 1,05 & 2,60 & 2,37 & 2,69 & 0,10 & 1,89 \\
\hline p33 & 2,6 & 57,92 & 13,65 & 28,43 & $c S$ & 31,45 & 3.35 & 3.00 & 4.70 & 4.59 & 0,49 & 0,74 \\
\hline p32 & 2,8 & 45,68 & 19.05 & 35,27 & $\mathrm{sC}$ & 58,74 & 1,83 & 5,00 & 5,13 & 5,43 & 0,01 & 0,76 \\
\hline p31 & 2,7 & 85,31 & 3,84 & 10,85 & $\mathrm{cS}$ & 32,03 & 0,60 & 2,45 & 2.07 & 3.05 & 0,04 & 1,91 \\
\hline p30 & 1,35 & 17,34 & 32,51 & 50,16 & sM & 28,16 & 3,96 & 8,00 & 6,12 & 3,50 & $-0,57$ & 1,50 \\
\hline p29 & 1,7 & 33,78 & 57,90 & 8,32 & $s Z$ & 17,16 & 4,18 & 6,50 & 5,53 & 2,71 & $-0,37$ & 0,83 \\
\hline p28 & - & 22,40 & 35,40 & 42,20 & sM & 27,2 & 3,82 & 8,15 & 6,85 & 4,45 & $-0,28$ & 0,80 \\
\hline $\mathrm{p} 27$ & 2,3 & 64,05 & 9,08 & 26,88 & $c S$ & 28,80 & 3,85 & 6,85 & 3,65 & 5,28 & 0,51 & 0,73 \\
\hline p26 & 2,7 & 54,04 & 21,09 & 24,88 & $\mathrm{~ms}$ & 44,06 & 1,71 & 3,20 & 4,00 & 4,94 & 0,21 & 0,87 \\
\hline $\mathrm{p} 25$ & $\cdot$ & 15,60 & 30,20 & 55,20 & $\mathrm{sM}$ & 27,90 & 4,2 & 0,00 & 5,40 & 2,55 & $-0,40$ & 1,40 \\
\hline p24 & 2,1 & 20,40 & 36,39 & 43,20 & SM & 26,39 & 3.96 & 7.50 & 6.90 & 4.55 & $-0,22$ & 1,38 \\
\hline $\mathrm{p} 23$ & 2,35 & 31,27 & 37,39 & 31,34 & SM & 58,42 & 1,68 & 6.80 & 5,48 & 3,66 & $-0,50$ & 0,87 \\
\hline$p 21$ & 1,4 & 25,54 & 51,76 & 22,70 & $s z$ & 17,06 & 4,23 & 6.90 & 5,80 & 3.29 & $-0,34$ & 0,92 \\
\hline $\mathrm{p} 20$ & 1,7 & 36,88 & 29,49 & 33,63 & $\mathrm{sM}$ & 39,97 & 3,15 & 6,00 & 6,03 & 4,57 & $-0,03$ & 0,99 \\
\hline p19 & 2,3 & 67,93 & 18,02 & 14,06 & $\mathrm{~ms}$ & 58,83 & 1,43 & 2,30 & 3,45 & 3,59 & 0,41 & 0,73 \\
\hline p18 & 0,7 & 98,39 & 0,83 & 0,78 & $s$ & 11,98 & 0,18 & 2,20 & 2,15 & 0,64 & $-0,30$ & 2,30 \\
\hline p17 & 1,55 & 96,20 & 0,87 & 2,93 & $s$ & 27,38 & 0,55 & 1,30 & 1,15 & 0,97 & -0.08 & 1,01 \\
\hline p16 & 1,7 & 49,52 & 8,11 & 42,37 & $\mathrm{sC}$ & 47,10 & 2,37 & 4,00 & 4,18 & 4,47 & 0,05 & 0,64 \\
\hline p15 & 1,95 & 77.83 & 4,25 & 17.92 & $c S$ & 64,72 & 1,50 & 0,20 & 2,00 & 5,63 & 0,44 & 1,27 \\
\hline p14 & 0,7 & 15,16 & 64,42 & 20,41 & $s z$ & 22,92 & 3,96 & 8,30 & 6,88 & 2,46 & $-0,91$ & 2,09 \\
\hline p13 & 2 & 37,38 & 30,77 & 31,85 & SM & 15,94 & 4,44 & 6.40 & 5.92 & 3.58 & $-0,08$ & 0,86 \\
\hline $\mathrm{p} 12$ & 1,95 & 89,99 & 6,68 & 3,33 & $\mathrm{~ms}$ & 56,16 & 0,63 & 2,50 & 2,37 & 1,50 & 0,10 & 2,16 \\
\hline p11 & 1,3 & 17,73 & 44,42 & 37,85 & SM & 29,69 & 3.54 & 7.00 & 6.92 & 3.81 & $-0,05$ & 1.28 \\
\hline $\mathrm{p} 10$ & 1,8 & 64,69 & 20,78 & 14,53 & $\mathrm{~ms}$ & 46,35 & 2,10 & 2,60 & 3,50 & 3,81 & 0,38 & 0,94 \\
\hline p9 & 1,95 & 89,74 & 3,38 & 6,87 & $\mathrm{cS}$ & 32,56 & 0,87 & 2.00 & 1,30 & 2,77 & $-0,25$ & 1,27 \\
\hline $\mathrm{p} 8$ & 0,35 & 100,00 & 0.00 & 0,00 & $s$ & 25,12 & 0,18 & 2,50 & 2,47 & 0,93 & $-0,38$ & 3,18 \\
\hline $\mathrm{p} 7$ & 1,2 & 51,17 & 25,56 & 23,28 & $\mathrm{~ms}$ & 35,99 & 3,69 & 3,80 & 4.50 & 4,16 & 0,26 & 0,83 \\
\hline p6 & 1,65 & 33,35 & 35,50 & 31,14 & sM & 32,83 & 4,08 & 6,50 & 5,57 & 4,03 & $-0,24$ & 0,85 \\
\hline p5 & 1,45 & 28,08 & 57,02 & 14,90 & $s Z$ & 32,24 & 3,41 & 6,40 & 5,17 & 3,69 & $-0,41$ & 1,16 \\
\hline $\mathrm{p} 4$ & 2,1 & 94,09 & 1,50 & 4,41 & $s$ & 32,07 & 0,68 & 2,40 & 2,23 & 1,31 & 0,02 & 1,73 \\
\hline p3 & 0,8 & 97,71 & 0,36 & 1,93 & $s$ & 11,38 & 0,08 & 2.50 & 2.50 & 0.88 & $-0,37$ & 3.07 \\
\hline $\mathrm{p} 2$ & 0,45 & 100,00 & 0,00 & 0,00 & $s$ & 23,63 & 0,15 & 2,35 & 1,97 & 1,22 & $-0,64$ & 2,41 \\
\hline p1 & 1,3 & 97,59 & 1,56 & 0,85 & $S$ & 11,09 & 0.10 & 1,10 & 0,67 & 1.97 & $-0,28$ & 0,73 \\
\hline
\end{tabular}


reaches $200-250 \mathrm{~m}$ with a relatively higher relief. According to the morphological classifycation of Zenkovitch and King (Duffy W. et al, 1989), the type of the barrier islands of the Pappas lagoon is characterized as complex "double Tombolo".

ii. Bathymetry (Fig. 4a).

As shown by the bathymetric map in Fig8a, the Pappas lagoon is an elongate basin which is characterized by a relatively gentle slope in the eastern margins (1:180), a nearly flat section in the center of the basin (1:600) and a sharp slope at the western margins $(1: 60)$ where the lagoon is limited by the limestone basement. The Pappas lagoon is a relatively deep lagoon with a mean depth of $1.8 \mathrm{~m}$ showing a tendency to become deeper in the western margins, where the depth has the maximum value of $3 \mathrm{~m}$.

iii. Sedimentology

a. Lithological types (Figs. 4b, 4c).

Seven lithological types were recognized: 1 . sand, 2. muddy sand, 3. clayey sand, 4. sandy silt, 5 . sandy clay, 6 .sandy mud and 7 . silt. The percentage of the skeletal remains in the previous lithological types, as sand fraction, ranges from $3 \%$ to $64 \%$, while in general the sandy fraction makes about the $20 \%-93 \%$ of the material of a clastic genesis. The surface distribution of the sand fraction shows the lower values just behind the east barrier island and the southern end of lagoon and the higher values in the rest of lagoon.

The main lithological type of the surface sediments is different for each section of the Pappas lagoon. The north part of the lagoon is mainly characterized by coarse lithological types namely sand, muddy sand and sandy silt and secondarily by the coarse lithological type of the clayey sand as well.

In the central part of the lagoon coarse- and fine-grained lithological types occurred. The muddy sand, clayey sand, sand, sandy silt and silt belong to the coarse-grained types. The first two types occur in the western margins of the central part, while the third type at the north end of its eastern margins. The fourth and fifth types occur as very small islands in its center and in its south part respectively. The sandy mud and sandy clay belong to the fine-grained types. These two types mainly extend from the eastern margins of the central part up to its center. More specifically, it could be said that almost $50 \%$ of the central part are covered by sandy mud. Certainly, the sandy mud and sandy clay are found in the western margins also, but as small islands.

Finally, the south part of lagoon is mostly characterized by the lithological types of the sandy mud and sandy clay (fine-grained lithological types) and secondarily by the lithological type of clayey sand (coarse-grained lithological type).

b. Median (Md) (Table 4).

The $M_{d}$ varies between $0.0 \varphi$ and $8.3 \varphi$ and the average $M_{d}$ is $4.39 \varphi$.

c. Mean size (Mz) (Fig.4d) (Table 4).

The $\mathrm{M}_{\mathrm{z}}$ varies between $0.67 \varphi$ and $7.92 \varphi$ and the average $M_{z}$ is $4.45 \varphi$. However, the distribution of mean size values shows two different parts along the longest axis of the lagoon. The first part, along the western margin of the lagoon is characterized by low $\varphi$ values in $\mathrm{M}_{\mathrm{z}}$. The second part, along the eastern margin of the lagoon is characterized by high $\varphi$ values in $\mathrm{M}_{\mathrm{z}}$.

d. Sorting (Fig. 4e) (Table 4).

The sorting fluctuates between $0.64 \varphi$ and $5.63 \varphi$ with an average value of $3.64 \varphi$. The sediments are moderately well sorted up to extremely poorly sorted. The better sorted sediments occur in the north part of the lagoon.

e. Skewness (Fig.4f) (Table 4).

The skewness varies from 0.91 to 0.79 . The near symmetrical sediments constitute the $25 \%$ of the lagoon, whereas $30 \%$ is represented by sediments with fine-skewed up to strongly fineskewed values and $45 \%$ by coarse-skewed up to strongly coarse-skewed values. The distribution pattern of the skewness is analogous with the distribution patterns of the sand fraction and the $M_{z}$ values (Figs. 29, 30, 32). Where the sand fraction has low values or the $M_{z}$ belongs to the medium silt up to the coarse clay class, the skewness is coarse-skewed while where the sand fraction has high values or the $M_{z}$ belongs to sand up to the coarse silt class, the skewness is fine-skewed. 
f. Kurtosis (Fig. 4g) (Table 4)

The kurtosis varies from 0.60 to 2.72. Most part of the lagoon is covered either by platykurtic /very platykurtic sediments (49\%) or by leptokurtic/very leptokurtic sediments (39\%). The rest of the lagoon is constituted only by $12 \%$ mesokurtic sediments.

g. Calcium carbonate (Fig.4h) (Table 4)

The content of $\mathrm{CaCO}_{3}$ in the sediments varies between $7,19 \%$ and $68,97 \%$, while the average value is $33,20 \%$. The spatial distribution of calcium carbonate shows that the $\mathrm{CaCO}_{3}$ low values which vary from $0 \%$ to $20 \%$, occur in the area nearby the inlets of lagoon and in its southern end. The intermediate values range from $20 \%$ to $40 \%$ and occur in the most part of the lagoon. High values more than $40 \%$ in $\mathrm{CaCO}_{3}$ characterize the western lagoon margin. There is no correlation between the carbonate content and the clay and silt fractions respectively $\left(R^{2}=0.001, R^{2}=0.07\right)$. However, if the sand samples are not plotted then there is a negative correlation between the carbonate content and the organic carbon for the remaining finer samples (R2=0.55).

h. Organic carbon (Fig.4i) (Table 4)

The percentage of organic carbon in the analyzed samples varies from $0.08 \%$ to $4.70 \%$ while the average value is $2.54 \%$. The spatial distribution of $\mathrm{C}_{\text {org }}$ values in the bottom of the lagoon indicates low values which are less than $1 \%$, mostly in the western area of the northern part of the lagoon. However, most part of the lagoon indicates high values which are more than $3 \%$. The intermediate values from $1 \%$ to $3 \%$ occur in the western margin of the central part of the lagoon. Organic content is positively correlated with mean size $\left(M_{z}\right)(R=0.72)$ and both silt and clay contents $\left(R^{2}=0.48, R^{2}=0.56\right)$.

Discussion

The northern part of the lagoon is mainly characterized by coarse-grained lithological types.

In the central part of the lagoon coarse- and fine-grained lithological types occur. The coarsegrained lithologies occur mostly in the west margin of the central part, while the fine-grained lithologies in its eastern margin. The southern part of the lagoon is composed mainly by fine- grained lithologies. The above arrangement of lithological types is directly related to the source areas. The northern part has as its main source area the sandy coastal and sub-coastal areas of the Ionian Sea. The central part receives sediments largely from its western margin and secondarily from the Patraikos Gulf at its eastern margin. The source areas of this margin are the terra rosa and talus apron of the existing there limestone volume and alluvial fans overlaying palaeo-dunes. The Patraikos Gulf, along the eastern lagoon barrier island can be characterized as a sandy starved area, because of the cyclone action along the barrier island coast (Papatheodorou \& Kontopoulos, 1998). The southern part receives mainly sediments from the drainage system of a relatively extensive muddy alluvial plain and secondarily from the there existing limestone volume.

The value of the grain size parameters as well as their distribution is related directly with the distribution of the lithological types. Graphic mean $\left(\mathrm{M}_{\mathrm{z}}\right)$ presents a wide spectrum of values, with a tendency to be decreased from the northern to its southern part. The degree of sorting is general poor. This is owed to the fact that a lagoon environment is an environment of low energy that produces poorly sorted sediments in combination with the type of the source area. The asymmetry has coarse-skewed values in the coarse-grained types (sandy materials), as expected, because these types occur in the northern part of the lagoon which has the Ionian marine sand as its source. In the central part of the lagoon the winnowing process produces sediments with fine-skewed asymmetry in its west margin and sediments with coarse-skewed asymmetry in the remainder section of the central part. In the southern part of the lagoon, sediments are characterized by coarse-skewed asymmetry because their source area offers sediments with the same asymmetry which does not change, due to the low energy environment. The sediments in the northern part of the lagoon are mostly lepto-kurtic as the sand fraction predominates. The sediments in the central part of the lagoon, and particularly in its eastern section, have a leptokurtic character as these are more mature and prevail the subpopulation ei- 
ther of the silt and clay or of the sand. In the western section of the central and southern part of the lagoon, the platycurtic sediments prevail as they appear to constitute a mixture of two populations, one sand population and one silt/clay population roughly in equal analogy. It is clear that the kurtosis in the Pappas lagoon is a measure of the relationships between the size modes, perhaps modified by the energy conditions. The negative relationship between the carbonate content and the organic content of the muddy sediments indicates that the carbonate one mostly has a clastic character. The positive relationship among the organic carbon and the mean size $\left(M_{z}\right)$, silt and clay fractions has been interpreted previously.

\section{CONCLUDING REMARKS}

On the basis of the previous discussions for each lagoon separately, it can be concluded that:

1. The studied lagoons are very shallow.

2. The sandy mud lithology is the dominant type of the lagoonal bottom sediments.

3. The bottom sediments are characterized as very poorly to extremely poorly sorted.

4. The studied lagoonal environment is one of a very low energy. In this environment the velocity of the depositional agent either fluctuates wide or presents greater consistency. The main hydraulic mechanism for the distribution of the bottom sediments is the winnowing effect by wind action.

5. The carbonate material shows increased abundance in the bottom sediments with an average value of about $35 \%$. This material is mostly clastic.

6. The organic carbon material shows increased abundance in the bottom sediments with an average value of about $3 \%$. This material is mostly clastic.

7. The presence of an abundant clay fraction in the lagoonal bottom sediments allows

the precipitation of organic carbon. The latter should be always evaluated when solution to environmental problems is required.

\section{BIBLIOGRAPHY}

Barnavas, S. P., 1979: Geochemistry of sediments from eastern Pacific. PhD thesis, University London, 431pp.

Buller, A. T. and MacManus, J., 1972: Simple metric sedimentary statistics used to recognize different environments. Sedimentology, 18, 1-21.

Dimopoulos, G. and Mountrakis, D., 1989: Hydrogeological and hydrochemical behavior of Kaiafa's hot springs (W. Peloponnese). Bull. Geol. Soc. Greece, XXIII/3, 49-60.

Duane, D.B., 1964: Significance of skewness in recent sediments, western Pamlico Sound, North Carolina. J. Sediment. Petrol., 34, 864-874.

Duffy, W., Belknap, D. F., and Kelley, I.T., 1989: Morphology and stratigraphy of small barrier lagoon systems in Main. Marine Geology, 88, 243-262.

Folk, R. L., 1974: Petrology of Sedimentary Rocks. Hemphill, Austin Texas, 182pp.

Folk, R. L. and Ward, W. S., 1957: Brazos River bar: a study in the significance of grain size parameters. Jour. Sed. Petr., 27(1), 3-26.

Gaudette H. E., Flight, W. R., Toner, L. and Folger, D. W., 1974: An inexpensive titration method for the determination of organic carbon in recent sediments. Jour. Sed. Petr., 44, 249-253.

Greenwood, B., 1969. Sediment parameters and environment discrimination: an application of multivariate statistics. Can. Jour. Earth Sci., 6 1327-1348.

Martins, L. R., 2003: Recent sediments and grain size analysis. Gravel, 1, 90-105, Porto Alegre, Brazil.

Panagos, A.G., Pe, G.G. and Gerouki, F., 1978: Detrital mineralogy of river sands, Peloponnese, Greece. N. Jb. Miner. Mh., 1978, $447-$ 454.

Papatheodorou, G. and Kontopoulos, N., 1998: Determination of sediment transport directions using the "McLaren Method". Examples from the Patras and Ambrakikos Gulfs, Greece. Bulletin of the Geological Society of Greece, vol. XXXII/2, 145-155.

Rullkötter, J. 1999. Organic Matter: The driving force for early diagenesis. In: Schulz, H.D. \& 
Zabel, M. (eds.). Marine Geochemistry, 129172, Springer, Berlin.

Valia, H. S. and Cameron, B., 1977: Skewness

as a paleoenvironmental indicator. Jour. Sed. Petr., 47(2), 784-793.

Tyson, R.V. 1995. Sedimentary organic matter: Organic Facies and Palynofacies. London, Chapman \& Hall, 615p. 